\title{
Abnormally Low Hemoglobin A1c as Harbinger of Hemoglobinopathy
}

\author{
Joshua St. Louis, MD, MPH and Anthony Valdini, MD, MS, MPH
}

Hemoglobin A1c is frequently used in primary care to screen for and monitor disorders of glucose metabolism. A number of clinical syndromes may impact the accuracy of this laboratory value. This report describes a case of abnormally low hemoglobin A1c that was the result of an asymptomatic compound hemoglobinopathy (homozygous hemoglobin $S$ disease and hereditary persistence of fetal hemoglobin) that had gone previously undiagnosed. Primary care physicians must be aware of such pitfalls in the use of this laboratory value and be prepared to use other values to monitor for and assess disorders of glucose metabolism. (J Am Board Fam Med 2019;32:923-924.)

Keyword: Diabetes Mellitus, Fetal Hemoglobin, Glucose, Glycated Hemoglobin A, Hematology, Hemoglobinopathies, Primary Care Physicians, Primary Health Care

Glycohemoglobin (hemoglobin A1c) is a form of hemoglobin that is bound to glucose. The level is used in the screening, diagnosis and management of diabetes mellitus. We describe a case of a 43 -year-old Dominican woman who, on routine screening, was found to have an abnormally low glycohemoglobin value as a result of a compound hemoglobinopathy. The discussion reviews the few causes of such an abnormally low value and the relevant follow-up.

\section{Case Report}

A 43-year-old nulliparous Dominican woman presented to establish care after immigrating to the United States. Her physical examination was within normal limits apart from obesity (Body mass index (BMI), $30.6 \mathrm{~kg} / \mathrm{m}^{2}$ ) and she had no complaints at the time of her visit. She was screened for type 2 diabetes mellitus using a hemoglobin A1c given her obesity, high-risk ethnic group, and age in addition to other

This article was externally peer reviewed.

Submitted 4 April 2019; revised 10 June 2019; accepted 11 June 2019.

From the Department of Family Medicine, Tufts University School of Medicine, Boston, MA (JSL); Department of Family Medicine, University of Massachusetts School of Medicine, Worcester, MA (Â).

Funding: none.

Conflict of interest: none declared.

Corresponding author: Joshua St. Louis, MD, MPH, Department of Family Medicine, Tufts University School of Medicine, 34 Haverhill Street, Lawerence, MA 01840 (E-mail: joshua.stlouis@glfhc.org). evidence-based screening tests. On return of her laboratory results, her hemoglobin A1c was noted to be $<3.5 \%$. The remainder of her screening tests were normal.

Given the abnormal A1c value, the patient was called back for further lab testing. A repeat A1c was done to rule out lab error as well as a fasting glucose, a complete blood count with indices, and fecal occult blood. The repeat A1c was again $<3.5 \%$ with fasting glucose of $95 \mathrm{mg} / \mathrm{dL}$. Fecal occult blood was negative for 3 samples. The complete blood count was essentially normal (hemoglobin, $12.2 \mathrm{~g} / \mathrm{dL}$; hematocrit, $34.5 \%$ ) with the exception of a low mean corpuscular volume of $76.2 \mathrm{fL}$ (normal, 82 to 100). The remainder of the indices were normal.

Given the microcytosis noted on the complete blood count (CBC) and elevated rate of hemoglobinopathies in this patient's ethnic group, a hemoglobin electrophoresis was performed and was markedly abnormal: $0 \%$ hemoglobin A, 36.3\% hemoglobin F, 3.9\% hemoglobin A2, and 59.8\% hemoglobin S. The interpretation of this electrophoresis was homozygosity of hemoglobin S (sicklecell disease) in combination with hereditary persistence of fetal hemoglobin.

\section{Discussion}

Hemoglobin A1c became available to clinicians in 1978 and was first recommended for clinical use by the American Diabetes Association a decade later in 
Table 1. Conditions Associated with False Alterations in A1c Level

\begin{tabular}{|c|c|}
\hline False Increase & False Decrease \\
\hline $\begin{array}{l}\text { Anemia (in particular those } \\
\text { associated with increased } \\
\text { red cell turnover) }\end{array}$ & $\begin{array}{l}\text { Anemia (from acute or } \\
\text { chronic blood loss) }\end{array}$ \\
\hline Asplenia & Splenomegaly \\
\hline Uremia & Pregnancy \\
\hline $\begin{array}{l}\text { Severe hypertriglyceridemia } \\
\quad(\text { typically }>1750 \mathrm{mg} / \mathrm{dL})\end{array}$ & Vitamin $\mathrm{E}$ ingestion \\
\hline $\begin{array}{l}\text { Severe hyperbilirubinemia } \\
\text { (typically }>20 \mathrm{mg} / \mathrm{dL} \text { ) }\end{array}$ & $\begin{array}{l}\text { Medications (ribavirin, } \\
\text { interferon-alpha) }\end{array}$ \\
\hline Chronic alcohol consumption & Red blood cell transfusion \\
\hline Chronic salicylate ingestion & $\begin{array}{l}\text { Hemoglobin variants } \\
\text { (most often with } \\
\text { homozygous } \\
\text { hemoglobinopathies) }\end{array}$ \\
\hline Chronic opioid ingestion & Vitamin $\mathrm{C}$ ingestion \\
\hline Lead poisoning & \\
\hline
\end{tabular}

Adapted from Radin, 2013, ${ }^{4}$ with permission.

1988. ${ }^{1}$ Various studies over the years have demonstrated the utility of hemoglobin A1c in predicting diabetes-related outcomes and complications. ${ }^{2,3}$ Since 2010, hemoglobin A1c has been recommended as one of the criteria that may be used for the diagnosis of diabetes, ${ }^{3}$ further expanding its clinical utility. Despite these benefits, a number of clinical scenarios may contribute to false results of this lab test. An excellent review by Radin ${ }^{4}$ reviews these potential conditions as noted in Table 1 .

Since hemoglobin A1c is a product of the glycosylation of hemoglobin $\mathrm{A}$, its use in patients with hemoglobinopathies may be less accurate for predicting disorders of glucose metabolism. ${ }^{5}$ This is particularly impactful on those hemoglobinopathies that demonstrate an abnormal quantity of hemoglobin A. In the case of our patient, her hemoglobin electrophoresis demonstrated $0 \%$ hemoglobin $\mathrm{A}$, which explains her A1c value of $<3.5 \%$. Other reviews have demonstrated that A1c seems to be most inaccurate in the case of homozygous hemoglobinopathies, ${ }^{6}$ which was also the case with our patient.

Since hemoglobin A1c cannot be used in these patients to screen for or monitor diabetes mellitus, clinicians may use another of the American Diabetes Association's recommended screening approaches; fasting plasma glucose $\geq 126 \mathrm{mg} / \mathrm{dL}$, random plasma glucose $\geq 200 \mathrm{mg} / \mathrm{dL}$ with classic symptoms of hyperglycemia, or plasma glucose $\geq$
$200 \mathrm{mg} / \mathrm{dL} 2$ hours after a 75-g glucose load. ${ }^{9}$ In terms of monitoring glycemic control, clinicians may consider either following a glucose log of both fasting and postprandial values or using other markers such as fructosamine. ${ }^{4}$

Of particular interest in this case was the presentation of co-occurring hemoglobinopathies with mitigating effects on one another. Our patient was homozygous for hemoglobin SS (sickle-cell disease) with $59.8 \%$ hemoglobin $\mathrm{S}$ on her electrophoresis. The usual morbidity and mortality of this condition, as well as the usual finding of profound anemia, were mitigated by the presence of hereditary persistence of hemoglobin F, a coinherited hemoglobinopathy whose effects protect erythrocytes from hemoglobin S polymer-induced damage. ${ }^{7}$ Both of these conditions are found at higher incidence in the patient's home country ${ }^{8}$ and in this case were revealed by her abnormally low hemoglobin A1c.

To see this article online, please go to: http://jabfm.org/content/ 32/6/923. full.

\section{References}

1. Sacks DB. Measurement of hemoglobin A(1c): a new twist on the path to harmony. Diabetes Care 2012; 35:2674-2680.

2. Little RR, Rohlfing CL, Sacks DB. Status of hemoglobin A1c measurement and goals for improvement: from chaos to order for improving diabetes care. Clin Chem 2011;57:205-214.

3. American Diabetes Association. Diagnosis and classification of diabetes mellitus. Diabetes Care 2010; 33(Suppl. 1):S62-S69.

4. Radin MS. Pitfalls in hemoglobin A1c measurement: when results may be misleading. J Gen Intern Med 2013;29:388-394.

5. Sacks DB. A1c versus glucose testing: a comparison. Diabetes Care 2011;34:518-523.

6. Smaldone A. Glycemic control and hemoglobinopathy: when A1c may not be reliable. Diabetes Spectrum 2008;21:46-49.

7. Ngo DA, Aygun B, Akinsheye I, et al. Fetal haemoglobin levels and haematological characteristics of compound heterozygotes for haemoglobin S and deletional hereditary persistence of fetal haemoglobin. Br J Haematol 2012;156:259-264.

8. Siddiqui S, Schunk K, Batista M, et al. Awareness of sickle cell among people of reproductive age: Dominicans and African Americans in northern Manhattan. J Urban Health 2012;89:53-58.

9. Pippitt K, Li M, Gurgle HE. Diabetes mellitus: screening and diagnosis. Am Fam Physician 2016;93:103109. 